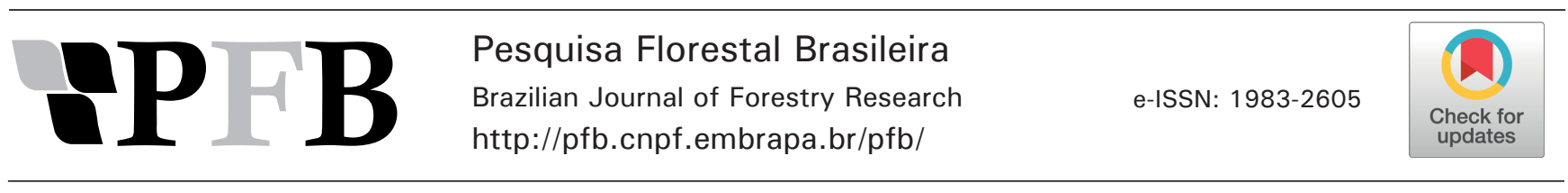

\title{
Alternative criteria to achieve sustainable management of Mezilaurus itauba in the Brazilian Amazon
}

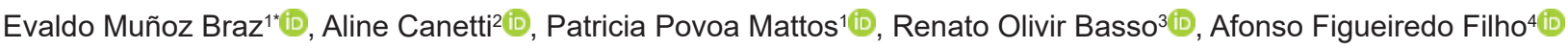 \\ ${ }^{1}$ Embrapa Florestas, Estrada da Ribeira, Km 111, CP. 319, CEP 83411-000, Colombo, PR, Brazil \\ ${ }^{2}$ Universidade Federal do Paraná, Av. Prefeito Lothário Meissner, 632, Jardim Botânico, CEP 80210-170, Curitiba, PR, Brazil \\ ${ }^{3}$ Elabore Projetos e Consultoria Florestal, Av. Gov. Júlio Campos, 207, St. Comercial, CEP 78550-000, Sinop, MT, Brazil \\ ${ }^{4}$ Universidade Estadual do Centro-Oeste, PR-153 - KM 7, Riozinho, CP. 121, CEP 84500-000 - Irati, PR, Brazil
}

"Corresponding author:

evaldo.braz@embrapa.br

Index terms:

Minimum logging diameter

Forest structure

Tropical forest

Termos para indexação:

Diâmetro mínimo de corte

Estrutura florestal

Floresta tropical

Received in 04/05/2018

Accepted in 17/09/2018

Published in 29/10/2018

doi: 10.4336/2018.pfb.38e201801648

\section{(c) $\underset{\mathrm{BY}}{\mathrm{N}} \mathrm{NC}_{\mathrm{ND}}$}

\begin{abstract}
The aims of this study were to evaluate the Brazilian law parameters for tropical forest management regarding forest recovery and to propose alternative criteria to achieve sustainability, using Mezilaurus itauba (Meisn.) Taub. ex Mez as case study. The diameter structure was obtained from a 100\% forest inventory of a 500 ha forest compartment. The assessment of $M$. itauba growth, ingrowth and mortality were carried out in a two sample plot of 50 ha located on the compartment, where all commercial species were measured both before and 7 years after logging. First it was evaluated the species structure and its most productive diameter class. The species recovery of timber volume has been simulated for the minimum logging diameter (MLD) of 50, 60,70 and $80 \mathrm{~cm}$. The largest volume recover was reached for the $60 \mathrm{~cm}$ MLD class. We showed that there is a diametric limit to achieve net timber volume production and that different remnant structures produce different increments.
\end{abstract}

\section{Critérios alternativos para alcançar o manejo sustentável de Mezilaurus itauba na Amazônia brasileira}

\begin{abstract}
Resumo - Os objetivos deste trabalho foram avaliar os parâmetros da legislação brasileira para o manejo de florestas tropicais quanto à recuperação da floresta e propor critérios alternativos para alcançar sua sustentabilidade, utilizando Mezilaurus itauba (Meisn.) Taub. ex Mez como caso de estudo. A estrutura diamétrica foi obtida de inventário $100 \%$ em um talhão de 500 ha. Os dados de crescimento, recrutamento e mortalidade de $M$. itauba foram adquiridos de 2 parcelas de 50 ha instaladas no talhão, em que todas as espécies comerciais foram medidas antes e após 7 anos da exploração. Foram avaliadas previamente a estrutura da espécie e sua classe diamétrica mais produtiva em volume. Posteriormente, foi simulada a recuperação em volume para os diâmetros limite de corte (DLC) de 50,60, 70 e $80 \mathrm{~cm}$. A maior produção ocorreu com DLC de $60 \mathrm{~cm}$. O trabalho evidenciou que existe um limite diamétrico para a produção líquida de volume de madeira e que distintas estruturas remanescentes produzem incrementos diferentes.
\end{abstract}

\section{Introduction}

In many municipalities of the Brazilian Amazon region, the management of natural forests is the only of model land use that ensures the maintenance of forest cover and that partially protects biodiversity (Putz et al.,
2012). Nowadays the forest management in Brazilian Amazon works with general criteria, where species inherent characteristics and site peculiarity are not considered. The forest law for Amazon management (Brasil, 2006) determines a cut cycle of 35 years and logging rate of $30 \mathrm{~m}^{3} \mathrm{ha}^{-1}$, where only trees with diameter 
at $1.3 \mathrm{~m}$ above ground level ( $\mathrm{dbh}$ ) bigger or equal to 50 $\mathrm{cm}$ can be logged and $10 \%$ of commercial trees have to be maintained in the forest as mother trees. For this reason, forest management is basically the extraction planning aiming low impact, considering the Amazon forest as a homogeneous structure. However, as Sist \& Ferreira (2007) emphasized, forest management is not sustainable when based only on low impact logging. Thus, when the same extraction rate is applied regardless tree species and forest structure, the forest recovery will depend on the original forest structure and tree species growth (Braz et al., 2012a).

The management of natural forests has been pointed along the last years as an unsustainable activity (Azevedo et al., 2008; Ruschel, 2008; Zimmerman \& Kormos, 2012; Reis et al., 2013; Castro \& Carvalho, 2014). However, what is usually neglected is that inadequate extractions cause inadequate recoveries (Schulze et al., 2008). Although it is not yet incorporated in productive systems, research results emphasize the possibility of calculating cut rates that would enable the forest recovery, when considering the diametric structure that should be set aside as remnant trees. They also include the growth pattern of the main species and the definition of the diameter classes that present the largest timber production during that growth cycle of a given species (Braz et al., 2011, 2012b).

The knowledge of growth pattern by species or group of species is considered as the basis to the development of more accurate and sustainable management protocols (Brienen \& Zuidema, 2005; Schongart, 2008; Braz et al., 2011).

The past and the future of the forest may be known by analyzing the forest diameter distribution, and it also contributes as auxiliary information for decisionmakers when planning forest management (Bettinger et al., 2009; Hossain et al., 2015; Orellana \& Figueiredo Filho, 2017). Production models are useful to obtain a diagnosis of forest structure and to model diametric variations, to establish optimum cutting cycles to define the economic feasibility of forest interventions, among other planning alternatives (Pulz, 1998). Mezilaurus itauba (Meisn.) Taub. ex Mez, known as itauba, is an important timber species from Amazon forest (Ribeiro et al., 2016). It occurs in upland forests along Amazon region (Mainieri \& Chimelo, 1978) and it was described as the fifth species considering the importance value index in Sinop region (Oliveira, 2014). It is a climax species, although it also regenerates easily in open areas (Lanssanova, 2012). M. itauba presents one of the highest timber values among few other species exploited in Mato Grosso State (Hummel et al., 2010). Despite of the importance to the regional economy, its management is not planned individually. It follows no regulation or understanding of the initial stock and the optimum remaining structure nor the growth pattern of the species.

The aims of this study were to evaluate the Brazilian law parameters for tropical forest management regarding forest recovery and to propose alternative criteria to achieve sustainability, using Mezilaurus itauba (Meisn.) Taub. ex Mez as study case. Analyzes and simulations of forest management usually consider the total set of tree species. This may mask the impact on the individual increment of each species. For this reason, in this work, only one species was selected. However, we consider that the species is under competition conditions of the whole compartment, which has 37 species in its total.

\section{Material and methods}

\section{Study area}

The data were obtained from a management compartment from a timber company located in Santa Carmen, Sinop micro-region, Mato Grosso State, Brazil. The Sinop micro-region is located in the South of Brazilian Amazon, representing 48,884 km² from 9 counties. According to Köppen classification, the region presents Aw climate, characterized as tropical warm and humid, having defined rainy and dry seasons (Alvares et al., 2013). Timber production is a tradition in the region, where no more than 15 species represent more than $90 \%$ of the timber commercially logged.

\section{Data collection}

The pre-harvest survey (100\% inventory) was carried out in a 500 ha forest compartment, measuring dbh with measuring tape and estimating the commercial height of all trees $\geq 30 \mathrm{~cm}$ of $\mathrm{dbh}$.

Timber volume was calculated using the form factor used by the forest company. In this survey, every Mezilaurus itauba tree was classified as "logging", "remnant" or "mother tree", according to the company planning. The trees were distributed in dbh classes of $10 \mathrm{~cm}$ interval. 
The periodic annual increment (PAI) by diameter class and the mortality rate of the trees were obtained from 2 permanent plots of 50 ha each, located in the studied compartment. All trees above $30 \mathrm{~cm}$ of dbh were measured in 2006 and 2013 using diametric tape. The PAI $_{\text {dbh }}$ was calculated as the dbh difference between the 2 measures divided by the period ( 7 years).

\section{Forest structure analysis}

The basal area per dbh class before logging was distributed as inferior $(\mathrm{dbh}<40 \mathrm{~cm})$, median (40 $\mathrm{cm} \geq \mathrm{dbh}>60 \mathrm{~cm})$ and superior strata $(\mathrm{dbh} \geq 60$ $\mathrm{cm})$ to evaluate in which stage of production is the compartment, according to Assmann (1970) definition (restocking, full production and canopy change).

The cumulative basal area by dbh class was calculated based on tree dbh and density before logging (trees ha ${ }^{-1}$ ). It was assumed that this distribution is similar as in previous periods in the same forest compartment.

\section{Most productive size class achievement}

Aiming to identify the dbh class with potential to produce greatest volume it was calculated the volume that each dbh class would contribute individually to the future total volume using the system of Alder (1992), adapted by Braz et al. (2011, 2012a). It was identified from each individual diameter class the timber volume that may be reached during the considered cut cycle. The proposed system, called "optimization of diameter classes in natural forests" (Braz et al., 2011) aims to determine which diameter classes, considering a certain starting point, contribute most to the final net volume.

The procedure followed for each dbh class was: 1) estimating the initial timber volume (V1), considering 100 trees per dbh class, giving all dbh classes the same opportunity; 2) simulating as presented in the next section the potential final volume (V2) of those trees for the 35 years cycle using dbh class projection according to the individual dbh class growth and mortality rate in the respective dbh class and period; 3) The net volume at the end of the new cycle was calculated as presented in equation (based in Davis \& Johnson, 1987).

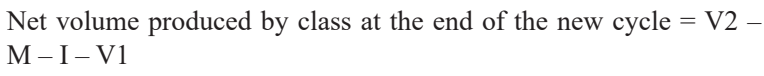

Where V1 = initial volume by class; V2 = final volume; $\mathrm{M}$ $=$ mortality rate at the size class evaluated in the period; I = ingrowth of size classes before evaluated one.

\section{Forest recovery simulation according to the minimum logging diameter (MLD)}

Remnant structures and the forest recovery potential considering timber volume were evaluated initially according to Brazilian forest law protocol (Brasil, 2006), with MLD of $50 \mathrm{~cm}$. After, we simulated the volume recover in which the volume obtained would be optimized, considering the MLD upper $60 \mathrm{~cm}$. We also simulated a cut cycle of 40 years. The goal was to seek the balance point between the cut rate and the recover capability for the second cut cycle.

For those simulations we applied the diameter class projection method proposed by Alder (1995). The forest structure was obtained from the $100 \%$ inventory data). It was always maintained $10 \%$ of commercial trees as mother trees. The method considers the outgrowth as calculated by equaiton 2 :

$$
O=\frac{t . i}{w}
$$

Where $0=$ outgrowth, $t=$ timing years, $i=$ increment in the dbh class, $w=$ dbh class width.

The recruitment considered was 5\% and the mortality rate was simulated for periods of five years for the next 35 years, applying the equation 3 :

$$
M_{d b h=} N(1-0.0 i)^{n}
$$

Where $M_{d h h}=$ mortality rate by dbh class, $N=N$ number of trees outgrowth dbh classes, $i=$ mortality rate and $n=$ cut cycle in years.

\section{Results}

Considering trees with $\mathrm{dbh} \geq 30 \mathrm{~cm}$, Mezilaurus itauba presented 1.5 trees $\mathrm{ha}^{-1}$ in the 500 ha compartment. It was measured 125 trees with an average diameter of 60 $\mathrm{cm}$, varying from dbh 30 to $120 \mathrm{~cm}$ (Figure 1). The dbh periodic annual increment was $0.20 \mathrm{~cm}^{\text {year }}{ }^{-1}$ and 0.26 $\mathrm{cm}$ year ${ }^{-1}$ when weighted by the number of trees per dbh class. This implies a mean passage time (PT) of 38 to 50 years between classes. Growth differences were observed among the different diameter classes (Figure 2 ) showing a lack of pattern. The mortality rate was low $\left(0.36 \%\right.$ year $\left.^{-1}\right)$ but increasing values were observed for trees in the dbh class of $75 \mathrm{~cm}$ or higher. 


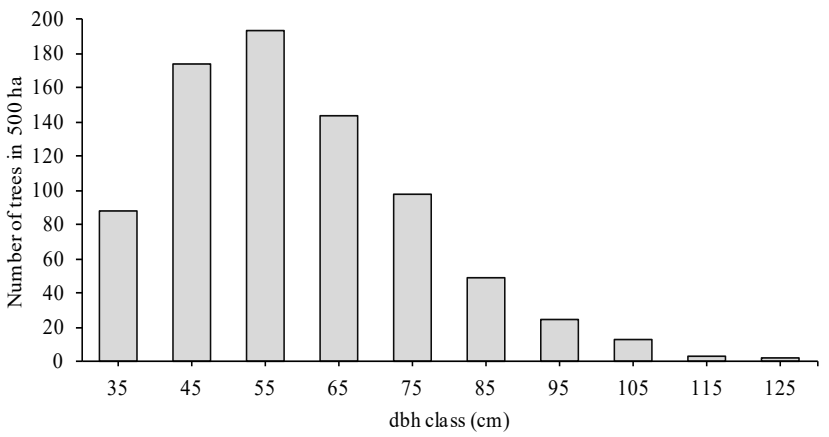

Figure 1. Diameter distribution of Mezilaurus itauba in 500 ha Amazon forest compartment, considering trees above 30 $\mathrm{cm}$ of dbh.

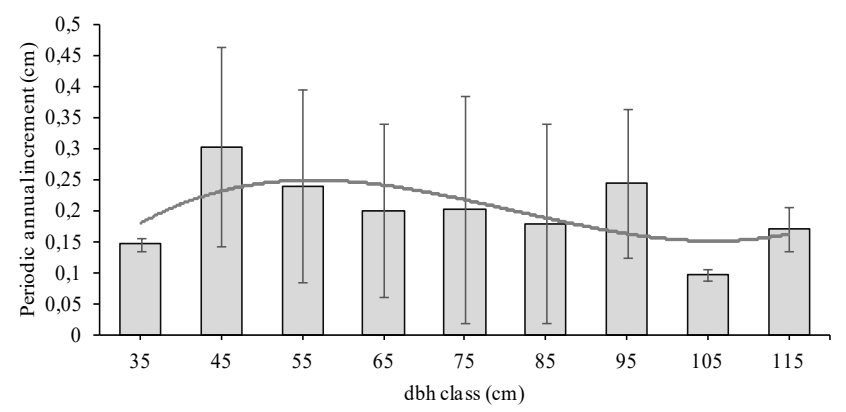

Figure 2. Increment by dbh class of Mezilaurus itauba in Amazon Forest compartment logged 7 years before.

By analyzing this forest compartment, it was possible to infer that the higher strata represented near $60 \%$ of the total stock, considering the starting point at $35 \mathrm{~cm}$ of dbh class (Figure 3). Moreover, the cumulative basal area culmination occurred soon after trees of $M$. itauba reached $70 \mathrm{~cm}$ of dbh (Figure 4). This shows that the accumulation of basal area tends to decline sharply after reaching $75 \mathrm{~cm}$ of dbh class.

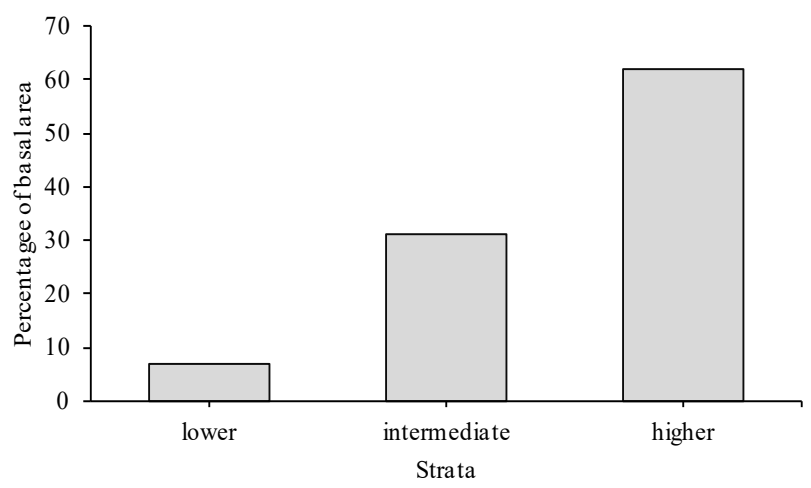

Figure 3. Percentage of basal area percentage in the lower, intermediate and higher strata.

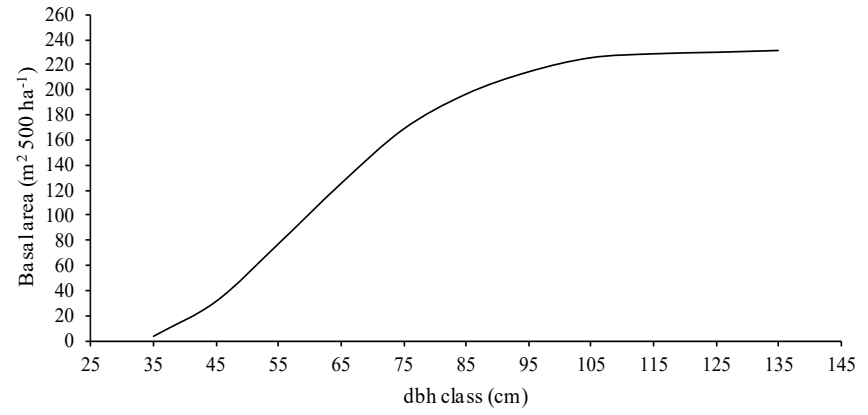

Figure 4. Cumulative basal area by dbh class of Mezilaurus itauba in 500 ha compartment, considering trees above 30 $\mathrm{cm}$ of dbh.

\section{Productive timber volume}

The available commercial timber volume of $M$. itauba in the compartment is $1,543.9 \mathrm{~m}^{3}$ (equivalent to $3.1 \mathrm{~m}^{3}$ $\mathrm{ha}^{-1}$ ), considering only those trees with $\mathrm{dbh} \geq 50 \mathrm{~cm}$, as specified on Brazilian forest law (Brasil, 2006).

After identifying the dbh class that can contribute with net increment to timber volume of the compartment, it may be seen that $55 \mathrm{~cm}$ of dbh class is the one that contributes most (Figure 5). The trees above the 75 $\mathrm{cm}$ class produce individually gross volume, but stop producing net volume from this point forward. This is due to an increase in mortality and reduction of the diameter increment in larger trees.

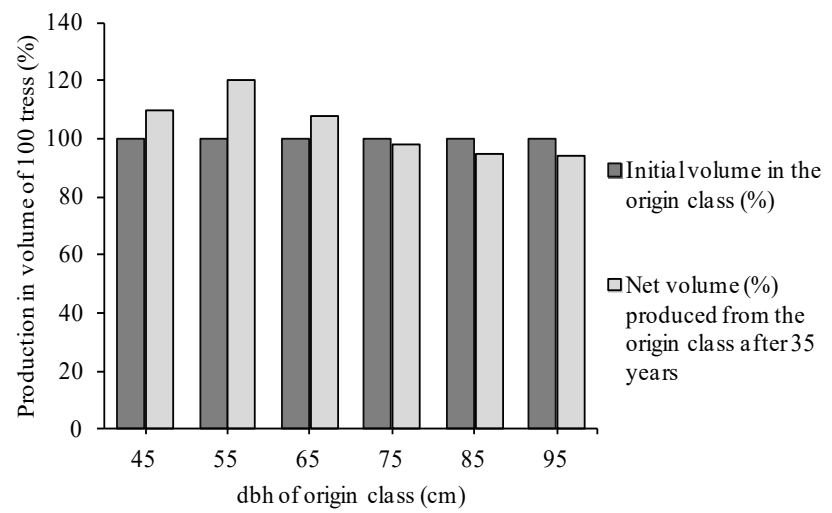

Figure 5. Percentage potential of net timber volume production of each origin dbh classes after 35 years.

\section{Timber volume recovery}

Timber volume recovery of $M$. itauba was different when applying different minimum logging diameter (MLD) but using the same cut cycles in the simulations (Figure 6). 


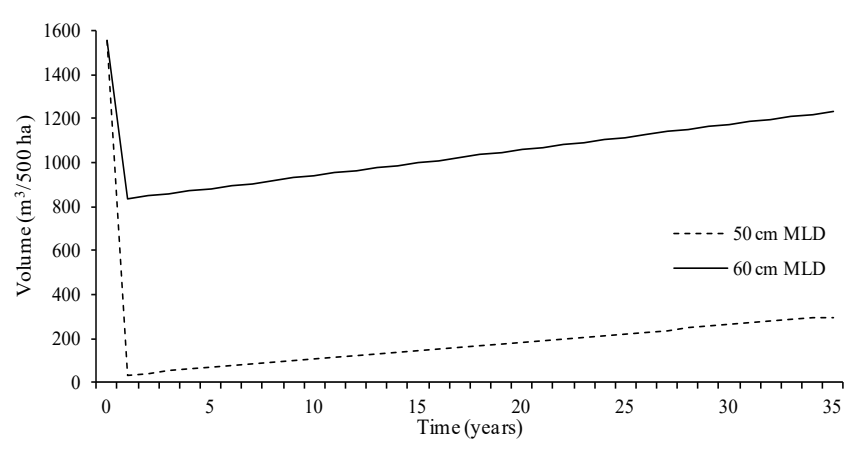

Figure 6. Simulation of timber volume recover in 500 ha compartment after logging of $M$. itauba trees, for $50 \mathrm{~cm}$ minimum logging diameter (MDL), according to Brazilian law (Brasil, 2006) and for a $60 \mathrm{~cm}$ MLD.

When considering Brazilian forest law (Brasil, 2006) parameters of $50 \mathrm{~cm}$ MLD and 35 years of cut cycle, the estimated projected volume increment of $M$. itauba was $0.015 \mathrm{~m}^{3} \mathrm{ha}^{-1}$ year-1, representing a net recovery of $21 \%$ of logged volume.

Understanding that $55 \mathrm{~cm}$ dbh class is the one with best volume production (Figure 5) and that it should be maintained in the forest, the second simulation was carried out considering a MLD of $60 \mathrm{~cm}$. In this case, the proposed cut rate was $46 \%$ of the original commercial timber volume and the net volume recovery was $57 \%$ of the logged volume, assuring $74 \%$ of original timber volume. In this simulation, timber volume increment would be $0.023 \mathrm{~m}^{3} \mathrm{ha}^{-1}$ year $^{-1}$ in a 35 years cycle. That is, this proposed cut rate produced $51 \%$ more timber volume than when applying criteria required by Brazilian law (Brasil, 2006).

The growth rate obtained by the simulation of a $70 \mathrm{~cm}$ MLD was $0.017 \mathrm{~m}^{3} \mathrm{ha}^{-1}$ and for an $80 \mathrm{~cm}$ MLD was $0.010 \mathrm{~m}^{3} \mathrm{ha}^{-1}$ year $^{-1}$, both below the obtained for the $60 \mathrm{~cm}$ MLD simulation. Considering Brazilian MLD of $50 \mathrm{~cm}$ and increasing the cut cycle for 40 years, the growth rate obtained was $0.012 \mathrm{~m}^{3} \mathrm{ha}^{-1}$ year ${ }^{-1}$.

\section{Discussion}

The frequency of Mezilaurus itauba observed in this study (Figure 1) is consistent with other studies carried out in the Amazon region. Ebert (2016) observed in Mato Grosso State 1.23 trees ha-1 $(\mathrm{dbh} \geq 30 \mathrm{~cm})$, very close to the density registered by Espírito-Santo (2005), in Nacional Forest of Tapajós, in Para State (1.15 trees ha $\left.{ }^{-1}\right)$.

Comparing with other species from the same region (Oliveira, 2015a, 2015b; Ribas, 2017), M. itauba presents smaller increments in diameter. However, similar increments were observed by Salomão et al. (2014) in a plantation of M. itauba in Porto Trombetas, Para State $\left(0.21 \mathrm{~cm}\right.$ year $\left.{ }^{-1}\right)$.

Despite the smaller individual growth in dbh, $M$. itauba ranks fifth among 37 species considering its abundance (Oliveira, 2014). This may possibly produce growth per hectare similar or higher than species with greater diameter increment but low in abundance.

Usually the growth at different dbh classes in natural forests is expected to be slower in smaller dbh, and it goes faster until it reaches the highest growth in bigger $\mathrm{dbh}$, followed by a gradual decline, as already pointed by Alder (1995); Brienen \& Zuidema (2005); Braz et al. (2012b), among others. However, M. itauba presented in this work a relatively constant mean increment after logging (Figure 2). The canopy opening seven years before may have favored growth due to higher light exposition, resulting in small differences of growth from trees at different diameter classes.

Assmann (1970) mentioned that the natural forests present three typical stages: restocking, full production and canopy change. In restocking stage, referred as construction stage, the canopy is covered by one third of each stratum (lower, intermediate and higher). In this stage, the higher stratum is not completely full. There is a tendency for this equilibrium to change, with increasing intermediate and higher strata as the forest grows older. In full production stage, the canopy is covered by over $50 \%$ of higher stratum. However, in Figure 3, it is possible to observe that in this compartment the upper stratum (before the management) reached $60 \%$. Also, in Figure 4 it can be seen that after the dbh class of $75 \mathrm{~cm}$ the basal area accumulation fast decreases until its total stagnancy. Then, according to Assmann (1970) and according to the concept described by Odum (1983), the compartment studied is achieving almost its maximum bearing production capacity, over $60 \%$ (Figure 3) and maximum carrying capacity to this species.

The high basal area in higher diameter classes implies in regeneration disturbances in lower dbh classes (Townsend et al., 2006; Schneider \& Finger, 2010), as it might be noticed in the $35 \mathrm{~cm}$ dbh class. Dawkins (1958) considers a possible stagnation of the forest growth when the basal area reaches its maximum. Moreover, Osmaston (1968) suggests that it is also possible to observe a negative increment (no net growth) in a virgin forest or when one that has been undisturbed for a long 
time. The increased mortality and reduced diameter growth in the larger classes plays an important role in this fact. This scenario was also pointed out by Braz et al. (2015), who explained the compartment as a forest that has already exceeded its optimum stock and increment potential.

For a minimum passage time of 38 years between dbh classes, trees from higher dbh classes $(\mathrm{dbh} \geq 100)$ would probably have already passed their point of maximum timber production for at least 150 years. Brienen \& Zuidema (2007) in Bolivian Amazon Forest observed similar results. The authors concluded for two species that the ideal minimum logging diameter (MLD) was already achieved many years before.

As the $55 \mathrm{~cm}$ dbh class is the most productive (Figure 5), its maintenance is essential to improve the volume recovery. Therefore, the recommended MLD for the species in the evaluated structure is $60 \mathrm{~cm}$.

The lower timber recovery (Figure 6) obtained when only applying law criteria (Brasil, 2006) and disregarding forest structure, its potential or management alternatives, is at similar levels to the results identified by many researchers (Van Gardingen et al., 2006; Sebbenn et al., 2008; Putz et al., 2012). However, low timber volume recovery itself does not reflect unsustainable management. It is more directly related to inadequate structure of remnant forest, and the increment and mortality rates for each dbh class of a certain species or group of species (Braz et al., 2012b). The increment varies according to remnant forest structure. Sustainability, therefore, depends on consideration of productive dbh classes and maximization of wood volume by forest managers. If those criteria are disregarded, the management expectations will be very dependent on chance.

In this work, it was possible to show that M. itauba presented increased growth and production when maintaining structures that favored productive dbh classes. Furthermore, management of $M$. itauba seems more adequate in 35 years cycles, due to lower annual increment in longer cycles.

The simulation of the net volume recovery for 40 years, considering the Brazilian law MLD $(50 \mathrm{~cm})$ produced a periodic annual growth lower than when simulating the 35 years cycle. That is, there is no commercial reason to enlarge the cycle, because when trees reach $75 \mathrm{~cm}$ dbh class center, there is no significant net increment of commercial wood volume. When associating this analysis with productive diameters, it is possible to conclude that there is a threshold to determine cut cycles of tree species from previously managed natural forests. If cut cycles and diameter thresholds are not taken into consideration, it is possible to have trees producing more timber volume, but the compartment net growth of timber volume will be lower (Braz et al., 2011). This threshold means that if the timber volume of the forest has reached its climax, it would be not possible to increase it any further, resulting in negative increment (no net growth), as discussed by Osmaston (1968). As it can be seen in the simulation, a MLD $\geq 70 \mathrm{~cm}$ reduces the growth of the species in the compartment. On the other hand, volume recovery can be improved by increasing the MLD to $60 \mathrm{~cm}$, but still it will not reach $100 \%$ of the first logging. This is because there is an excess of old trees at that moment. Brienen \& Zuidema (2007) and Dawkins \& Philip (1998) discussed the unavailability of recovering similar timber volume in a second cycle from old and big trees available in the first cut cycle, implying that recovering the total timber volume in the whole stand could demand extremely long and low productive cycles. In fact, the recovery rarely reaches $100 \%$ of the logged volume for any species, because this would imply reaching diameter classes that are beginning its stagnation or are at complete senescence already. The permanence of $75 \mathrm{~cm}$ or higher dbh classes, by example, will result in an accumulated timber volume deficit when compared to the same trees timber volume in the beginning of the cycle. For this reason, when trees pass the last productive dbh class, the timber volume produced is not economically viable due to smaller increment and high mortality rate, as observed by Braz et al. (2012b) in the state of Amazonas.

Bessides the MLD of $60 \mathrm{~cm}$, the one which produced more volume, the other MLDs tested presented growths gradually reduced. So, it is suggested that, without the knowledge of the MLD and the ideal cycle, management claims are arbitrary. By example, when an analysis considers the forest management as unsustainable, showing extractions that do not permit the full recovery of the timber volume extracted (Sebben et al., 2008; Zimmerman \& Kormos, 2012; Lacerda et al., 2013), it is important to confirm that the authors calculate what the remnant structure should have been before the forest intervention. Braz et al. (2011) studying Cedrela odorata L. from Amazon Forest showed that different remaining structures of the same species produced different volume recoveries. 


\section{Conclusion}

Optimum cut cycle, minimum logging diameter (MLD), productive dbh classes and an adjusted forest remnant structure depend on technical inferences, suggesting that fixed criteria, laid down by law, limit sustainable forest management.

Timber volume recovery of a productive forest is not the same as recovery of all timber volume logged, as it depends on original forest timber stock.

Mezilaurus itauba as a study case gives an example that may be applied to other tree species when defining MLD. Cut cycle of different commercial species should be a balance of cycles and structure calculated for each species.

Strategies to increase forest production based on the procedure proposed in this paper, such as using a cycle or MLD that maximizes timber volume, must still be complemented by economic analysis.

\section{References}

Alder, D. Growth modelling for mixed tropical forests. Oxford: Oxford Forestry Institute, University of Oxford, 1995. 231 p.

Alder, D. Simple methods for calculating minimum diameter and sustainable yield in mixed tropical Forest. In: Miller, F. R. \& Adam, K. L. (Ed). Wise management of tropical forests. Oxford: Oxford Forest Institute, 1992. p. 189-200

Alvares, C. A. et al. Köppen's climate classification map for Brazil. Meteorologische Zeitschrift, v. 22, n. 6, p. 711-728, 2013. DOI: 10.1127/0941-2948/2013/0507.

Assmann, E. Principles of forest yield study. New York: Pergamon Press, 1970. 506 p.

Azevedo, C. P. et al. Simulação de estratégias de manejo florestal na Amazônia com o uso do modelo SYMFOR. Acta Amazônica, v. 38, n. 1, p. 51-70, 2008. DOI: 10.1590/S0044-59672008000100007.

Bettinger, P. et al. Forest management and planning. Press, New York: Academic, 2009. 331 p.

Brasil. Ministério do Meio Ambiente. Instrução normativa $n^{\circ} .05$ de 11 de dezembro de 2006. Diário Oficial [da] República Federativa do Brasil, Brasília, DF, n. 238, p. 155-9, 13 dez. 2006.

Braz, E. M. et al. Otimização da distribuição diamétrica remanescente da espécie Cedrela odorata no estado do Acre, visando o novo ciclo. In: SIMPÓSIO LATINO-AMERICANO SOBRE MANEJO FLORESTAL, 5., 2011, Santa Maria, RS. Sustentabilidade florestal: [anais]. Santa Maria, RS: UFSM, Programa de Pós-Graduação em Engenharia Florestal, 2011. p. 183-193.

Braz, E. M. et al. Strategies for achieving sustainable logging rate in the Brazilian Amazon Forest. Open Journal of Forestry, v, 4, n. 2, p. 100-105, 2015. DOI: 10.4236/ojf.2014.42015.
Braz, E. M. et al. Taxa de corte sustentável para manejo de florestas tropicais. Ciência Florestal, v. 22, n. 1, p. 137-145, 2012a. DOI: $10.5902 / 198050985086$.

Braz, E. M. Subsídios para o planejamento do manejo de florestas tropicais da Amazônia. 2010. 236 f. Tese (Doutorado em Engenharia Florestal) - Universidade Federal de Santa Maria, Santa Maria, RS.

Braz, E. M. et al. Manejo da estrutura diamétrica remanescente de florestas tropicais. Ciência Florestal, v. 22, n. 4, p. 787-794, 2012b. DOI: 10.5902/198050987559.

Brienen, R. J. W. \& Zuidema, P. A. Incorporating persistent tree growth differences increases estimates of tropical timber yield. Frontiers in ecology and the environment, v. 5, n. 6, p. 302-306, 2007. DOI: 10.1890/1540-9295(2007)5[302:RCPTGD]2.0.CO;2.

Brienen, R. J. W. \& Zuidema, P. A. Lifetime growth patterns and ages of Bolivian rain forest trees obtained by tree ring analysis. Journal of Ecology, v. 94, n. 1, p. 481-493, 2005. DOI: 10.1111/j.13652745.2005.01080.x.

Davis, L. S. \& Johnson, K. N. Forest management. 3rd. ed. New York: McGraw-Hill, 1987. 790 p.

Castro, T. C. \& Carvalho, J. O. P. Dinâmica da população de Manilkara huberi (Ducke) A. Chev. durante 26 anos após a exploração florestal em uma área de terra firme na Amazônia brasileira. Ciência Florestal, v. 24, n. 1, 2014. DOI: 10.5902/1980509813333.

Davis, L. S. \& Johnson, K. N. Forest management. 3rd ed. New York: McGraw-Hill, 1987. 790 p.

Dawkins, H. C. \& Philip, M. S. Tropical moist forest silviculture and management: a history of success and failure. Wallingford: $\mathrm{Cab}$ International, $1998.359 \mathrm{p}$.

Dawkins, H. C. The management of the natural tropical high forest with special reference to Uganda. Oxford: Imperial Forestry Institute, University of Oxford, 1958. 155 p. (Institute paper, 34).

Ebert, A. et al. Spatial distribution pattern of Mezilaurus itauba (Meins.) Taub. Ex mez. in a seasonal forest area of the southern Amazon, Brazil. iForest-Biogeosciences and Forestry, v. 9, n. 3, p. 497, 2016.

Espírito-Santo, F. D. B., et al. Análise da composição florística e fitossociológica da floresta nacional do Tapajós com o apoio geográfico de imagens de satélites. Acta Amazônica, v. 35, n. 2, p. 155-173, 2005. DOI: 10.1590/S0044-59672005000200006.

Hossain, M. A. et al. Composition and diversity of tree species in kamalachari natural forest of chittagong south forest Division, Bangladesh. Journal of Forest and Environmental Science, v. 31, n. 3, p. 192-201, 2015.

Hummel, A. C. et al. A atividade madeireira na Amazônia brasileira: produção, receita e mercados. Belém: Serviço Florestal Brasileiro e Instituto do Homem e Meio Ambiente da Amazônia, 2010. 32 p.

Lacerda, A. E. B et al. Modeling the long-term impacts of logging on genetic diversity and demography of Hymenaea courbaril. Forest Science, v. 59, n. 1, p. 15-26, 2013. DOI: 10.5849/forsci.10-118.

Lanssanova, L. R. Ajuste de funções de afilamento para espécies florestais comerciais do bioma Amazônico Matogrossense. 2012. 165 f. Dissertação (Mestrado em Engenharia Florestal) Universidade Federal de Mato Grosso, Cuiabá. 
Mainieri, C. \& Chimelo J. P. Fichas de características de madeiras brasileiras. São Paulo: Instituto de Pesquisas Tecnológicas, 1978. $418 \mathrm{p}$.

Odum, E. P. (Ed.). Ecologia. Rio de Janeiro: Guanabara, 1983. 434 p.

Oliveira, M. F. Critérios para o manejo sustentável de duas espécies madeireiras das florestas naturais do Mato Grosso. 2014. 114 f. Dissertação (Mestrado em Engenharia Florestal) Universidade Federal do Paraná, Curitiba.

Oliveira, M. F et al. Padrão de crescimento e diâmetro ótimo de corte de cambará no município de Santa Carmem, microrregião de Sinop, MT. Colombo: Embrapa Florestas, 2015a. (Embrapa Florestas. Comunicado técnico, 364).

Oliveira, M. F. et al. Padrão de crescimento e diâmetro ótimo de corte de cupiúba na microrregião de Sinop, MT. Colombo: Embrapa Florestas, 2015b. 5 p. (Embrapa Florestas. Comunicado técnico, 369).

Orellana, E. \& Figueiredo Filho, A. Uso do método da predição de parâmetros para projetar a distribuição diamétrica em florestas nativas com a função Weibull. Ciência Florestal, v. 27, n. 3, 2017. DOI: $10.5902 / 1980509828670$.

Osmaston, F. C. The management of forests. Londres: George Allen and Unwin, $1968.384 \mathrm{p}$.

Pulz, F. A. Estudo da dinâmica e a modelagem da estrutura diamétrica de uma floresta semidecídua montana na região de Lavras - MG. 1998. 165 f. Dissertação (Mestrado em Engenharia Florestal) - Universidade Federal de Lavras, Lavras.

Putz, F. E. et al. Sustaining conservation values in selectively logged tropical forests: the attained and the attainable. Conservation Letters, v. 5, n. 1, p. 296-303, 2012. DOI: 10.1111/j.1755263X.2012.00242.x.

Reis, L. P. et al. Efeito da exploração de impacto reduzido em algumas espécies de Sapotaceae no leste da Amazônia. Floresta, v. 43, n. 3, p. 395-406, 2013. DOI: 10.5380/rf.v43i3.30808.

Ribas, H. E. R. Padrão de crescimento de amescla em Santa Carmem, MT. Colombo: Embrapa Florestas, 2017. 7 p. (Embrapa Florestas. Comunicado técnico, 406).
Ribeiro, E. S. et al. Espécies florestais comercializadas pelo estado de Mato Grosso. Biodiversidade, v. 15, n. 02, 2016.

Ruschel, A. R. Dinâmica da composição florística e do crescimento de uma floresta explorada há 18 anos na flona Tapajós, PA. Belém, PA: Embrapa Amazônia Oriental, 2008. 57 p. (Embrapa Amazônia Oriental. Documentos, 341).

Salomão, R. P. et al. Dinâmica de reflorestamento em áreas de restauração após mineração em unidade de conservação na Amazônia. Revista Árvore, v. 38, n. 1, p. 1-24, 2014. DOI: 10.1590/ S0100-67622014000100001.

Schneider, P. R. \& Finger, C. A. G. Manejo sustentado de florestas inequiâneas heterogêneas. Santa Maria, RS: Departamento de Ciências Florestais, Universidade Federal de Santa Maria, 2010. $195 \mathrm{p}$.

Schongart, J. Growth-Oriented Logging (GOL): a new concept towards sustainable forest management in Central Amazonian varzea floodplains. Forest Ecology and Management, v. 256, n. 1-2, p. 46-58, 2008. DOI: 10.1016/j.foreco.2008.03.037.

Schulze, M. et al. How rare is too rare to harvest?: management challenges posed by timber species occurring at low densities in the Brazilian Amazon. Forest Ecology and Management, v. 256, n. 7, p. 1443-1457, 2008. DOI: 10.1016/j.foreco.2008.02.051.

Sebbenn, A. et al. Modelling the long-term impacts of selective logging on genetic diversity and demographic structure of four tropical tree species in the Amazon forest. Forest Ecology and Management, v. 254, n. 1, p. 335-339, 2008. DOI: 10.1016/j. foreco.2007.08.009.

Sist, P. \& Fereira. F. N. Sustainability of reduced-impact logging in the Eastern Amazon. Forest Ecology and Management, v. 243, n. 1, p. 199-209, 2007. DOI: 10.1016/j.foreco.2007.02.014.

Townsend, C. R. et al. Fundamentos em ecologia. 2. ed. Porto Alegre: Artmed, 2006. 576 p.

Van Gardingen, P. R. et al. Evaluation of yield regulation options for primary forest in Tapajo's National Forest, Brazil. Forest Ecology and Management, v. 231, n. 1, p. 184-195, 2006. DOI: 10.1016/j. foreco.2006.05.047.

Zimmerman, B. L. \& Kormos, C. F. Prospects for sustainable logging in tropical forests. BioScience, v. 62, n. 5, p. 479-487, 2012. DOI:10.1525/bio.2012.62.5. 